\title{
Prevalence of high serum uric acid is increased in ambulatory subjects with hyperglycemia and dyslipidemia
}

Primeira submissão em 31/03/10 Última submissão em 26/04/10 Aceito para publicação em 28/04/10 Publicado em 20/08/10

\section{A prevalência de hiperuricemia está aumentada em pacientes ambulatoriais com hiperglicemia e dislipidemia}

Tânia Torres Rosa'; Ewandro Luiz Rey Moura²; Manuela Costa de Oliveira3; Gláucia Boff ; Luiz Fernando Junqueira Jr. ${ }^{5}$; Joel Paulo Russomano Veiga ${ }^{6}$

key words

Ambulatory subjects

Hyperuricemia

Hyperglycemia

Dyslipidemia

\section{abstract}

Introduction: Serum uric acid has been considered a marker or an element of the clinical and laboratory alterations in the metabolic syndrome. Objective: to evaluate the association between levels of serum uric acid (UA) and the following laboratory profile: fasting glucose $\geq 100 \mathrm{mg} / \mathrm{dl}$, triglycerides $\geq 150 \mathrm{mg} / \mathrm{dl}$ and high density lipoprotein cholesterol (HDL-C) $<50 \mathrm{mg} / \mathrm{dl}$ in women and $<40 \mathrm{mg} / \mathrm{dl}$ in men. Method: In a cross-sectional survey, blood samples of 4,328 randomized outpatients aged from 20 to 102 years were analyzed. Results: The mean (interquartile range) UA level was higher in men $(6.7 ; 2.4-12.5 \mathrm{mg} / \mathrm{dl})$ and women $(5.4 ; 2.0-12.2 \mathrm{mg} / \mathrm{dl})$ with the laboratorial profile than in those without it $(5.9 ; 0.90-33.8 \mathrm{mg} / \mathrm{dl}$ for men and $4.4 ; 0.8-30.0 \mathrm{mg} / \mathrm{dl}$ for women) $(p<0.0001)$. A significant increase in the prevalence of laboratory profile was observed in men $(\mathrm{OR}=2.2 \mathrm{mg} / \mathrm{dl} ; 95 \% \mathrm{Cl}: 1.2-3.9 \mathrm{mg} / \mathrm{dl})$ and women $(\mathrm{OR}=2.2 \mathrm{mg} / \mathrm{dl} ; 95 \% \mathrm{Cl}: 1.4-3.5 \mathrm{mg} / \mathrm{dl})$ with hyperuricemia. Conclusion: These results show the association between serum levels of uric acid and metabolic syndrome profile, which corroborates to similar results found in other populations worldwide.

\section{resumo}

Introdução: O ácido úrico sérico tem sido considerado um marcador ou componente das alterações clínicas e laboratoriais da síndrome metabólica. Objetivo: Avaliar a associação entre o ácido úrico sérico $(A U)$ e o perfil laboratorial composto de glicemia de jejum $\geq 100 \mathrm{mg} / \mathrm{dl}$, triglicerídeos $\geq 150 \mathrm{mg} / \mathrm{dl}$ e colesterol da lipoproteína de alta densidade $(\mathrm{HDL}-\mathrm{C})<50 \mathrm{mg} / \mathrm{dl}$ nas mulheres e $<40 \mathrm{mg} / \mathrm{dl}$ nos homens. Método: Em estudo de corte transversal, amostras de sangue de 4.328 pacientes ambulatoriais não selecionados com idade variando de 20 a 102 anos foram examinadas. Resultados: A mediana (variação interquartil) do $A U$ foi mais elevada nos homens $(6,7 ; 2,4-12,5 \mathrm{mg} / \mathrm{dl})$ e mulheres $(5,4 ; 2-12,2 \mathrm{mg} / \mathrm{dl})$ que apresentaram o perfil laboratorial do que nos que não o apresentaram $(5,9 ; 0,9-33,8 \mathrm{mg} / \mathrm{dl}$ para os homens e 4,4; 0,8-30 mg/dl para as mulheres) $(\mathrm{p}<0,0001)$. Observou-se aumento significativo na prevalência do perfil laboratorial nos homens (razão de chance $[R C]=2,2 \mathrm{mg} / \mathrm{dl}$; intervalo de confiança [IC] 95\%: 1,2-3,9 mg/dl) e mulheres ( $R C=2,2 \mathrm{mg} / \mathrm{dl} ;$ IC 95\%: 1,4-3,5 mg/dl) com hiperuricemia. Conclusão: Esses resultados mostram a associação dos níveis séricos do acido úrico com o perfil laboratorial da síndrome metabólica nesse grupo não selecionado de indivíduos brasileiros atendidos ambulatorialmente, sendo este um achado semelhante ao observado em outras populações estudadas mundialmente.

\section{unitermos}

Pacientes ambulatoriais

Hiperuricemia

Hiperglicemia

Dislipidemia

\footnotetext{
1. Doutora em Clínica Médica-Nefrologia pela Faculdade de Medicina de Ribeirão Preto da Universidade de São Paulo (FMRP-USP); professora associada de Clínica Médica da Faculdade de Medicina da Universidade de Braślia (FM-UnB).

2. Graduando em Medicina; bolsista do programa de iniciação científica da UnB; médico residente.

3. Graduanda em Medicina; bolsista do programa de iniciação científica da UnB; médica residente.

4. Farmacêutica bioquímica do Laboratório de Patologia Clínica do Hospital Universitário de Brasilia.

5. Doutor em Clínica Médica-Cardiologia pela FMRP-USP; professor titular de Clínica Médica da FM-UnB.

6. Doutor em Clínica Médica-Nefrologia; professor associado de Clínica Médica da FM-UnB.

Suporte financeiro: Programa de Iniciação Cientf́ica da Universidade de Brasilia e Conselho Nacional de Desenvolvimento Científico e Tecnológico (CNPq).
} 


\section{Introduction}

The investigation of different factors or risk markers is an important clinical task to prevent several chronic diseases, particularly cardiovascular ones. Many of these risks are well defined while others need to be identified. One relevant risk condition to health is the metabolic syndrome (MS), which comprises a cluster of combined clinical and laboratory abnormalities, including increased waist circumference, overweight or obesity, dyslipidemia, systemic arterial hypertension, and glucose intolerance or type Il diabetes, all of which reflect insulin resistance and constitute important atherogenic risk factors ${ }^{(4)}$. Individuals with MS still have increased susceptibility to fatty liver, polycystic ovary, asthma, sleep disturbances, and an increased risk for renal and atherosclerotic cardiovascular disease $\mathrm{s}^{(10,11,13,18)}$.

Although the components of MS may suggest its diagnostic when combined, not a single specific marker of the disease exists, and the presence of at least three of those alterations is the requirement for diagnostic of the syndrome ${ }^{(10,11)}$. Uric acid (UA) is not considered a criterion for the diagnosis of MS, but some studies have shown an association between high levels of UA and the syndrome in different populations ${ }^{(3,7,15,17,21)}$. This is a very important fact because levels of UA can vary in different populations, they are easily measured in a routine fashion, and can help in the identification of the syndrome by investigating for established risk factors. Furthermore, different populations worldwide may have distinctive metabolic peculiarities.

In the present work, we aimed to transversally evaluate, in an unselected sample of ambulatory subjects, the association between $\mathrm{UA}$ and a laboratory profile comprising hyperglycemia, hypertriglyceridemia and low HDL-C, which constitute the established laboratory criteria for the diagnostic of MS according to the revised National Cholesterol Education Program Adult Treatment Panel III (NCEP/ATPIII) $^{(4)}$ revised in $2005^{(11)}$.

\section{Method}

\section{Study population}

This was a retrospective cross-sectional survey based on a laboratory database of blood examinations from the Clinical Pathology Central Laboratory of the Brasilia University Hospital, Brasília, DF, Brazil. The study was conducted between 2002 and 2004 and blood samples of 4,331 ambulatory subjects assisted in this hospital, 20 years old or older, of whom 1,464 were men (33.8\%) and 2,864 were women (66.2\%), participated in the survey. Subjects came to the hospital for blood collection and general laboratory examination as part of their routine evaluation for different clinical conditions. For each subject examined only one laboratory examination result was obtained, so that the number of examinations was equal to the number of subjects.

\section{Laboratory data}

Individual blood samples were collected in the morning after an overnight fasting period of at least 12 hours. Serum lipid profile including high-density lipoprotein fractions of cholesterol (HDL-C) and triglycerides (TG) was obtained, in addition to serum fasting glucose (FG) and UA.

Elevated serum glucose was defined as fasting glucose $\geq 100 \mathrm{mg} / \mathrm{dl}$, and high HDL-C when serum concentration was $>40 \mathrm{mg} / \mathrm{dl}$ in men and $>50 \mathrm{mg} / \mathrm{dl}$ in women. Hypertriglyceridemia was characterized as serum TC concentration $\geq 150 \mathrm{mg} / \mathrm{dl}$.

In order to verify the prevalence of the altered laboratory profile in association with the level of UA, the latter was stratified into three levels, having as the cutoff the upper quartile ( $75^{\text {th }}$ percentile) of the range of values for the whole group of subjects according to gender: $\leq 4.8,4.9$ to 7.2 and $>7.2 \mathrm{mg} / \mathrm{dl}$ for men and $\leq 3.4,3.5$ to 5.5 and $>5.5 \mathrm{mg} / \mathrm{dl}$ for women. Hyperuricemia was defined as UA concentration $>6 \mathrm{mg} / \mathrm{dl}$ in men and $>5 \mathrm{mg} / \mathrm{dl}$ in women, based on reference values in our population using the specified laboratory method.

Levels of serum TG, glucose, and UA were determined by enzymatic techniques, and the level of HDL-C was measured using the monophasic colorimetric method without precipitation, with a biochemical autoanalyser (Mega $^{\circledR}$ Bayer, Germany) $)^{(19)}$.

\section{Statistical analysis}

The normality of distribution of laboratory data and UA concentration, discriminated by gender according to different age groups, was initially tested by the KolmogorovSmirnov test. Considering that they showed a skewed non-normal distribution, the median (interquartile range) of continuous laboratory variables was compared between age-grouped men and women employing the Kruskal-Wallis test with post-doc Dunns Multiple Comparison Test. The median of serum UA in subjects with and without the altered 
laboratory profile was compared in both genders employing the Mann-Whitney test. Proportions of categorical variables were compared using the chi-squared test. The odds ratio $(95 \% \mathrm{Cl})$ was calculated for the association between altered laboratory profile and serum UA stratified into three concentration levels. A statistically significant association or difference between variables was considered when a twotailed $p$ value was equal to or less than $5 \%(p \leq 0.05)$, and a weak or trend statistical significance when $P$ value was between $5 \%$ and $10 \%(0.05 \leq p \leq 0.1)$. Processing analysis and graphic design of the data employed the SigmaStat ${ }^{\circledR}$ 3.11/SigmaPlot 9.01 for Windows (Systat Software, Inc., USA, 2004) and the Prism 4 for Windows ${ }^{\circledast}$ (GraphPad Software, Inc., USA, 2005) software packages.

\section{Results}

Prevalence of metabolic abnormalities analyzed by gender and age was marginally greater in women $(9.04 \%$, $259 / 2864)$ than in men $(7.17 \%, 122 / 1464)(p=0.06)$. According to gender discriminated by age, prevalence of the altered laboratory profile in the age range of 20 39 was statistically similar in men $(4.45 \%, 15 / 337)$ and women $(3.86 \%, 25 / 646)(p=0.49)$; in the age range of $40-59$ the alterations also occurred similarly in men $(8.75 \%, 55 / 628)$ and women $(9.78 \%, 136 / 1,390)$ $(p=0.24)$. Differently, in the age range of 60 years and over, metabolic alterations were observed to be more prevalent in women $(11.83 \%, 98 / 828)$ than in men $(7.01 \%, 35 / 499)(p<0.001)$. The altered laboratory profile increased directly with age in both genders, except for men older than 60 years (Figure 1).

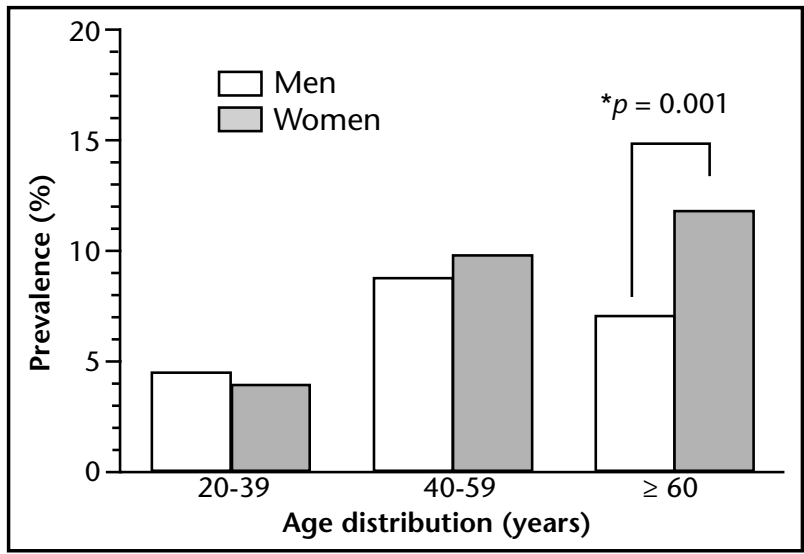

Figure 1 - Prevalence of laboratory profile of the metabolic syndrome in men and women according to age distribution

${ }^{*} \mathrm{p}$-value for the comparison between men and women in each age range (chi-square test).
Considering the full age range, the median (interquartile range) concentration of UA was observed to be significantly higher in men $(6.0 ; 0.9-33.8 \mathrm{mg} / \mathrm{dl})$ as compared to women $(4.4 ; 0.8-30 \mathrm{mg} / \mathrm{dl})$. Also, UA levels increased with age in both men $(p=0.003)$ and women $(p<0.0001)$. Comparisons between groups of men and women for each age range showed $p<0.0001$ for each one (Figure 2).

In subjects with the laboratory profile the median of UA was higher than in those without it for both genders in the different age ranges $(p=0.02 \leq 0.0001)$ (Figure 3). Regarding the association between serum concentration of UA and the altered laboratory profile for the overall age range, a higher median concentration of UA was found in

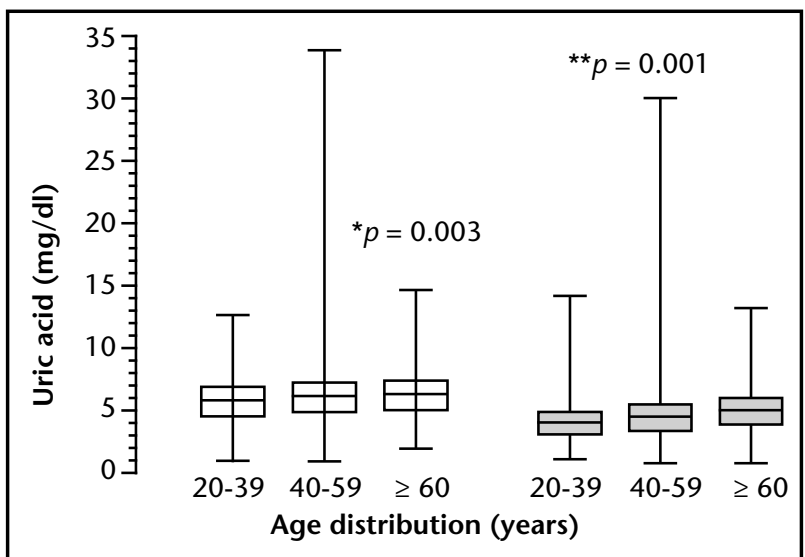

Figure 2 - Median (interquartile range) of serum uric acid in men (left clear boxes) and women (right dark boxes) according to age distribution

${ }^{*} \mathrm{p}$-value for the comparison between groups of men with the three different age ranges, and ${ }^{* *} \mathrm{p}$-value for the comparison between groups of women with the three different age ranges (Kuskal-Wallis test). Each pair-wised comparison between the groups with the different age ranges, for both men and women, showed a $\mathrm{p}<0.001$; by the post-hoc Dunn's multiple comparison test. Comparisons between the groups of men and women for each age range showed a $\mathrm{p}<0.0001$; (Mann-Whitney test)

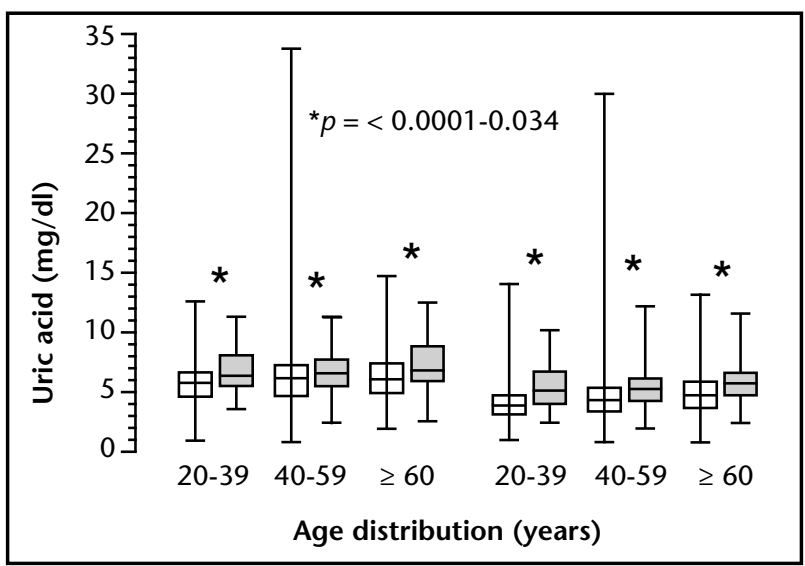

Figure 3 - Serum uric acid in men (left block of comparisons) and women (right block of comparisons) with (dark boxes) and without (white boxes) the laboratory profile of metabolic syndrome, according to age distribution

${ }^{*} \mathrm{p}$-values for the comparisons between subjects with and without the laboratory profile of MS in each age range (Mann-Whitney test). The data are expressed as median(interquartile range). 
men with alterations $(6.7 ; 2.4-12.5 \mathrm{mg} / \mathrm{dl})$ compared with those without it $(5.9 ; 0.90-33.8 \mathrm{mg} / \mathrm{dl})(p<0.0001)$. The same was observed in women with the alterations (5.4; $2-12.2 \mathrm{mg} / \mathrm{dl})$ in relation to those without it $(4.4 ; 0.8$ $30 \mathrm{mg} / \mathrm{dl})(p<0.0001)$.

Men with serum UA concentration equal to or greater than $7.2 \mathrm{mg} / \mathrm{dl}$ (upper quartile) had a 2.21-fold increase in the prevalence of the altered laboratory profile $(95 \% \mathrm{Cl}$, 1.24-3.94), compared with those who had concentrations equal to or less than $4.8 \mathrm{mg} / \mathrm{dL}$ (lower quartile). Among women, prevalence of the altered profile was 2.26 -fold greater for those with serum UA concentration between 3.5 and $5.5 \mathrm{mg} / \mathrm{dl}(95 \% \mathrm{Cl}, 1.45-3.53)$, and 5.26 -fold greater when serum UA was above $5.5 \mathrm{mg} / \mathrm{dl}(95 \% \mathrm{Cl}, 3.36-8.22)$, as compared with those who had concentrations of UA equal to or less than $3.4 \mathrm{mg} / \mathrm{dl}$ (Table).

\section{Discussion}

As expected, prevalence of the altered laboratory profile, established as a component of the diagnosis of metabolic syndrome, increased as the population becomes older, especially in women. In the group of women, the subset of those who were 60 years old or older showed the highest prevalence of the metabolic alteration, as compared to men in the same age range. This finding may be justified by a reduced estrogenic protection in the advanced climacteric period, where cardiovascular risk is higher, which is in accordance with other studies ${ }^{(9,22,27)}$. This period in a woman's life is associated with higher levels of LDL-C and lower levels of HDL-C ${ }^{(16)}$. Regardless of this particularity, it is a well- established fact that the defined altered laboratory profile is associated with a higher risk of cardiovascular disease, diabetes mellitus II, microalbuminuria, and renal disease in both genders in any age range ${ }^{(13,18)}$.
High levels of LDL cholesterol and triglycerides and low levels of HDL cholesterol increase the cardiovascular risk two fold in healthy adults ${ }^{(24,28)}$. The atherogenic risk factor $\mathrm{TC} / \mathrm{HDL}-\mathrm{C}$ ratio had a strong association with coronary heart disease ${ }^{(2)}$. Concurrent hypertriglyceridemia and low HDL-C are typical of insulin-resistant subjects and they constitute significant risk factors for cardiovascular disease ${ }^{(1)}$.

But the relevant finding in our study was that, in any age range, both men and women with the laboratory metabolic alteration also showed increased levels of serum UA. Although UA is not included in the criteria for the diagnosis of metabolic syndrome, other studies have also shown a strong association between high serum concentrations of UA and this syndrome or its clinical and/or laboratory components ${ }^{(3,7,15,17,21)}$. Recently, Sui et al. ${ }^{(26)}$, in a prospective study of 8,429 men and 1,260 women (20-82 years old) showed that higher serum UA is a strong and independent predictor of incident metabolic syndrome in men and women.

A possible explanation for the association between increased UA and the metabolic alterations which represent a hyperinsulinemic state would be the stimulant role of insulin on the reabsorption of sodium and urate in the proximal renal tubule ${ }^{(20,23)}$. In fact, the degree of insulin tolerance is inversely related to the renal clearance of urate $^{(5)}$. On the other hand, one independent association of TG and UA was previously demonstrated, and increased TG levels may be associated with decreased UA renal excretion $^{(8)}$.

Therefore, hyperuricemia may signal the presence of metabolic syndrome and it may also be an additional risk factor for the development of the clinical complications associated with the syndrome. In consequence, it seems important to routinely investigate serum UA level when this syndrome is suspected or when conventional laboratory

Table 1 Odds ratio $(95 \% \mathrm{Cl})$ for the association between the laboratory profile of metabolic syndrome and serum concentration of uric acid in unselected Brazilian ambulatory patients aged 20-102 years

\begin{tabular}{c|ccc|ccc}
\hline & \multicolumn{2}{|c|}{ Men (uric acid concentration, $\mathrm{mg} / \mathrm{dl}$ ) } & \multicolumn{3}{c}{ Women (uric acid concentration, mg/dl) } \\
& $\leq 4.8$ & $4.9-7.2$ & 7.2 & $\leq 3.4$ & $3.5-5.5$ & $>5.5$ \\
$\mathrm{~N}$ & 373 & 704 & 387 & 731 & 1.419 & 714 \\
$\mathrm{OR}$ & 1 & 1.3 & $2.2^{*}$ & 1 & $2.2^{* *}$ & $5.2^{* *}$ \\
$\mathrm{Cl}$ & - & $0.8-2.4$ & $1.2-3.9$ & - & $1.4-3.5$ & $3.3-8.2$ \\
\hline
\end{tabular}

$N$ : number of subjects; OR: odds ratio; $\mathrm{Cl}$ : confidence interval.

${ }^{*} \mathrm{p}=0.009 ;{ }^{* *} \mathrm{p}=0.001$ (chi-square test). 
alterations of the syndrome are encountered. On the other hand, when hyperuricemia is detected, the search for conventional markers of the syndrome should always be considered.

Furthermore, evidence suggests a relationship between UA levels and hypertension ${ }^{(12)}$. Hyperuricemia is also associated with endothelial dysfunction ${ }^{(29)}$, which may contribute to increase cardiovascular risk in hypertensive subjects. Moreover, hyperuricemia may be an important risk factor for kidney disease and may lead to the development and faster progression of renal disease ${ }^{(6,14,25)}$.

One limitation of this study was its retrospective design. This type of design and analysis, together with an ambulatory population evaluated for a multiplicity of clinical, conditions, inherently increases the likelihood that bias influenced our findings. To this respect, we attempted to minimize bias by analyzing all patients who met the study inclusion criteria. Another limitation was that several confounding variables, in a non-healthy population that attended to the hospital for several reasons, could not be adjusted because the respective data were not obtained. Also, there is a possibility that older patients or patients with metabolic syndrome and arterial hypertension might be using diuretics or other drugs that could eventually increase uric acid levels. However, our objective was to identify an association between UA concentration and the laboratory profile, regardless of other possible comorbidities, and it is very unlikely that only some subjects in use of drugs can affect the results.

In conclusion, in a cross-sectional survey of a Brazilian unselected ambulatory population, serum concentration of UA was higher in men than in women and increased with age in both genders. In all age ranges and more frequently in women, hyperuricemia stratified in three levels was associated with a clustered laboratory alteration represented by hyperglycemia, hypertriglyceridemia and low HDL-C. In men the frequency of the altered laboratory profile was higher when UA concentration was greater than $7.2 \mathrm{mg} / \mathrm{dl}$. These findings suggest that high levels of UA are a comorbiditie and may be a marker or component of an altered metabolic profile represented by the metabolic syndrome. Hyperuricemia should be considered an additional risk factor for different clinical conditions, which demand treatment. To our knowledge, this is the first observation about the association between the clustered laboratory components of metabolic syndrome and hyperuricemia, in an unselected Brazilian population, reproducing similar findings verified in other populations worldwide.

\section{Acknowledgements}

The authors acknowledge the financial support of PIC-UnB/CNPq and Mrs. Carolina Cunha for their help in revising the English language.

\section{References}

1. ASSMANN, G.; SCHULTE, H. Relation of high-density lipoprotein cholesterol and triglycerides to incidence of atherosclerotic coronary artery disease (the PROCAM experience).Prospective Cardiovascular Münster study. Am J Cardiol, v. 70, p. 733-7, 1992.

2. CASTELLI, W. P.; ABBOTT, R. D.; MCNAMARA, P. M. Summary estimates of cholesterol used to predict coronary heart disease. Circulation, v. 67, p. 730-4, 1983.

3. $\mathrm{CHOI}, \mathrm{H}$. K.; FORD, E. S. Prevalence of the metabolic syndrome in individuals with hyperuricemia. Am J Med, v. 120, p. 442-7, 2007.

4. EXECUTIVE summary of the third report of the National Cholesterol Education Program (NCEP) Expert Panel on Detection, Evaluation and Treatment of High Blood Cholesterol in Adults (Adult Treatment Panel III). JAMA, v. 285, p. 2486-97, 2001.

5. FACCHINI, F. et al. Relationship between resistance to insulin-mediated glucose uptake, urinary uric acid clearance, and plasma uric acid concentration. JAMA, v. 266, p. 3008-11, 1991.

6. FEIG, D. I. Uric acid: a novel mediator and marker of risk in chronic kidney disease? Curr Opin Nephrol Hypertens, v. 18, p. 526-30, 2009.

7. FORD, E. S. et al. Serum concentrations of uric acid and the metabolic syndrome among US children and adolescents. Circulation, v. 115, p. 2526-32, 2007.

8. GIACOMELLO, A.; DI SCIASCIO, N.; QUARATINO, C. P. Relation between serum triglyceride level, serum urate concentration, and fractional urate excretion. Metabolism, v. 46, p. 1085-9, 1997.

9. GORODESKI, G. I. Update on cardiovascular disease in post-menopausal women. Best Pract Res Clin Obstet Gynaecol, v. 16, p. 329-55, 2002.

10. GRUNDY, S. M. etal. Definition of Metabolic Syndrome Report of the National Heart, Lung, and Blood Institute/American Heart Association Conference on Scientific Issues Related to Definition. Circulation, v. 109, p. 433-8, 2004. 
11. GRUNDY, S. M. et al. Diagnosis and management of the metabolic syndrome. An American Heart Association/ National Heart, Lung, and Blood Institute Scientific Statement. Circulation, v. 112, p. 2735-52, 2005.

12. HEINIG, M.; JOHNSON, R. J. Role of uric acid in hypertension, renal disease, and metabolic syndrome. Cleve Clin J Med, v. 73, p. 1059-64, 2006.

13. I DIRETRIZ BRASILEIRA DE DIAGNÓSTICO E TRATAMENTO DA SÍNDROME METABÓLICA. Arq Bras Cardiol, v. 84, p. 1-28, 2005.

14. JOHNSON, R. J. et al. Reappraisal of the pathogenesis and consequences of hyperuricemia in hypertension, cardiovascular disease, and renal disease. Am J Kidney Dis, v. 33, p. 225-34, 1999.

15. KAWAMOTO, R. et al. Relationship between serum uric acid concentration, metabolic syndrome and carotid atherosclerosis. Intern Med, v. 45, p. 605-14, 2006.

16. KULLER, L. H, et al. Epidemiologic studies of menopause: changes in risk factors and disease. Exp Gerontol, v. 29, p. 495-509, 1994.

17. LEE, J. et al. Uric acid and coronary heart disease risk: evidence for a role of uric acid in the obesity-insulin resistance syndrome: The Normative Aging Study. Am J Epidemiol, v. 142, p. 288-94, 1995.

18. LOCATELLI, F.; POZZONI, P.; DEL VECCHIO, L. Renal manifestations in the metabolic syndrome. J Am Soc Nephrol, v. 17, p. S81-85, 2006.

19. MCNAMARA, J. R.; SCHAEFER, E. J. Automated enzymatic standardized lipid analyses for plasma lipoprotein fractions. Clin Chem Acta, v. 166, p. 1-8, 1987.
20. MUSCELLI, E. et al. Effect of insulin on renal sodium and uric acid handling in essential hypertension. Am J Hypertens, v. 9, p. 746-52, 1996.

21. NAKAGAWA, T. et al. A causal role for uric acid in fructoseinduced metabolic syndrome. Am J Physiol, v. 290, p. F625-31, 2006.

22. OLIVEIRA, A.; FILHO, J. M. Perfil nutricional e lipídico de mulheres na pós-menopausa com doença arterial coronariana. Arq Bras Cardiol, v. 4, p. 325-9, 2005.

23. QUIÑONES GALVAN, A. et al. Effect of insulin on uric acid excretion in humans. Am J Physiol, v. 268, p. E1-5, 1995.

24. RIDKER, P. M. High-sensitivity C-reactive protein: potential adjunct for global risk assessment in the primary prevention of cardiovascular disease. Circulation, v. 103, p. 1813-8, 2001.

25. SIU, Y. P. et al. Use of allopurinol in slowing the progression of renal disease through its ability to lower serum uric acid level. Am J. Kidney Dis, v. 47, p. 51-9, 2006.

26. SUI, X. et al. Uric acid and the development of metabolic syndrome in women and men. Metabolism, v. 57, p. 845-52, 2008.

27. WELTY, F. K. Women and cardiovascular risk. Am J Cardiol, v. 88, Supp I, p. 48J-52J, 2001.

28. WILSON, P. W. Established risk factors and coronary artery disease: the Framingham Study. Am J Hypertens, v. 7, p. 7S-12S, 1994.

29. ZOCCALI, C. et al. Uric acid and endothelial dysfunction in essential hypertension. J Am Soc Nephrol, v. 17, p. 1466-71, 2006. 